\title{
Brahmanism: A Religious Cult in Ancient India
}

\author{
Dr. Dinesh Kumar
}

Assistant Professor, Amity School of Liberal Arts, Amity University Haryana, India

\begin{abstract}
The article on Brahmanism in ancient Indian society will show various aspects of Indian tradition and culture by exploring the foundational elements and prerequisites of it. Brahmanism as a distinct religious tradition in ancient India was largely confined to the northern parts of the Indian subcontinent. The founding texts are discussed by exploring the sruties of ancient India. The article shows that Brahmanism has not only been an active religious tradition in ancient India but it had passed through different difficult phases throughout the historical development of various religions across the country. Brahmanism has a long past in the Indian continent, but at the same time, it has faced many challenges by the other religions as well.
\end{abstract}

Keywords-Brahmanism, Shruti, Brahmanic culture, Indian culture.

\section{INTRODUCTION}

The birth of Brahmanism has no specific time rather it is a development of philosophical ideas in different stages that mostly relied on its religious texts and rituals. It has been opposed by the other religions for its orthodox elements. The period 200BC to AD 300 has witnessed the origin revival of Brahmanical tradition and culture in ancient India. It received the professed support for Vedic rituals and sacrificial activities from various kings. Dynasties of Shungas and Kanvas were a staunch supporter of Brahmanism. Brahmanism in the long course of development strongly, opposed by Buddhism and Jainism. Many philosophical principles were under attack of these two non-Brahmanic traditions around $6^{\text {th }}$ century BC. On the other hand, several philosophical principles of ancient Indian religions are similar in many ways and transmit the same ideas from one generation to other. Around 500 before the Common Era, Brahmanism dominated religious, ethical, philosophical, and social system. Brahmanism did not remain the same as it was in the beginning but many changes also occurred in the course of religious development. The foundation of Brahmanism is its philosophical principles and conception of society.

Many of the historians believe that Brahmanism is a continuation of Vedic tradition and culture, which was brought to India by the Aryans around 1500 BC. To a great extent, it is accepted that Brahmanism is an outgrowth of Vedism, so it can't be separated from Vedism. ${ }^{1}$ The

\footnotetext{
${ }^{1}$ M.M., Williams, Brahmanism and Hinduism or Religious Thought and Life in India: as Based on the Veda and other
}

development of Brahmanism is a gradual process unlike the development of other religions. It was the time of the Aryan invasion in India and created Indian culture. In many sense, Brahmanism is the antecedent of Hinduism, which started taking shape around 4th century BC. With the advent of Brahmanism, the concept of existence changed. There is a strong belief in reincarnations, which once for all has been installed in the Brahmanical society and thus became an integral element. The idea of reincarnation in Brahmanism has not only created a cultural dogma in Indian religious tradition but also a pessimistic feeling took possession of it. There is a deep sense that human existence passes through various forms of suffering, and it is reiterated in the successive and countless re-existences through which man has to go in every birth unless he achieves the liberation (moksha).

\section{FOUNDATION OF BRAHMANISM \\ A) Shruti-( Vedas, Brāhmaṇas, Araṇaṇas and Upnishads)}

The foundation of Brahmanism mostly relies on Shruti ${ }^{2}$ a sacred knowledge in ancient India. Shruti is translated as "Revelation," since it holds a distinct feature of life and afterwards. Many important texts of ancient India such as

Sacred Books of the Hindus, New York, Macmillan and Co., 1891.

2 A word derived from the root "Sru" (to hear)-it represents a sacred knowledge system that is orally transmitted from one generation to other. 
the Vedas, the Brāhmanas, Aranyañas and Upnishads ${ }^{3}$ are the part of Shruti. These religious and philosophical texts of ancient India are believed to be full of the ultimate notion of truth. These texts also provide the answers to all questions that are raised by a man, solutions to all kinds of illusion, the existence of the universe, and the origin of every sentient being. In Brahmanism, it is also believed that Shruties are helpful to regulate the society and social institutions not only in ancient India but also even in modern times in many ways.

The founding texts of Brahmanism are not the only regulator of society but also describe the role of gods, ceremonies, and rites in human lives. In Brahmanism worshipping, is inevitable for the followers of it, to keep them safe from any kind of abnormality in life it is a unique way to obtain the kindness and protection of Gods, and thus the order between the universe and human society is maintained. There is also a belief that the texts, which are prime support for the Brahmanism, have not been composed by any human or transcendent being rather they exist since a beginning-less entity. ${ }^{4}$

The founding texts of Brahmanism are thus not dependent on anything or anybody, somewhat independent and divine and so by their own power they describe the destiny of a man, sages, seers, rishis and poets of ancient India in various means. On the other side, Shruties also explain the creation and destruction of everything in this universe. The mysterious nature of the religious texts of Brahmanism fixe the limits of human knowledge and restrict them within a defined boundary. The respect and submission of the followers to these Brahmanic texts determine the authority of one's own belonging to Brahmanism. In other words, one has to accept the authority of the religious texts to express his/her association with it. In the real sense, Brahmanism is centred on metaphysical structure, ostentatious outcrop, setoff believes, speculations, and logics of many great sages.

\section{PREREQUISITES OF BRAHMANISM}

3 Jan Gonda, Vedic Literature, Wiesbaden: Otto Harrassowitz, 1975, and M. Winternitz, A History of Indian Literature, Vol. I, Introduction, Veda, National Epics, Puraṇas and Tantras, New Delhi: Oriental Books Reprint Corporation, 1972.

4 F. Tola and C. Dragonetti, "Anāditva or beginninglessness in Indian Philosophy", in Annals of the Bhandarkar Oriental Research Institute, Vol. LXI, 1980, pp. 12-14, and "El anāditva (inexistencia de comienzo) en la Filosofía de la India", in Revista Venezolana de Filosofía No. 13, 1980, pp. 140-143.
There are various essential parts of Brahmanism, which are as follows'

a.) Brahman- Brahman in the Indian society since the early days is the Absolute, the Truth of the Truth or a holy figure, Unique in all other Varnas, one who has the privileged status in the society. He is the deepest fundament of reality in society, beyond reason and word, and the position of a Brahman can be reached by an extra-ordinary yogic experience in the course of a spiritual abstraction. In Brahmanism, the Brahman is always kept away from anything that could be the reason behind the material association of him. It is practised to mark him "the other." $\mathrm{He}$ has been acknowledged supreme and designated supernatural duties in society. They are supposed to describe everything that is beyond the reach of senses for others. Moreover, the primary task of Brahmanism was creating a hierarchy order into Brahman, kshatriya, vaisya and Sudra. Such types of hierarchal orders are not noticed in the nonBrahmanic religions. ${ }^{6}$

b.) Ātman - another essential part or element of Brahmanism is the concept of Ātman. It is understood as the spirit, the soul, the individual consciousness. The concept of Atman is considered to be pure very mystical in Brahmanic texts. In fact, because of the notions of Brahman and Atman in Brahmanism, it is well thought-out a substantial and unitary system of thought. ${ }^{7}$ For the authors of Upnishads the concept of Atman is eternal and it important for conscious beings and it is identical with the essence of all beingBrahman. In other sense, atman is Brahman. ${ }^{8}$

c.) Karman-In Brahmanism, the existence of the people is conditioned by the merits and demerits they attain through good and bad deeds in their previous lives. Many of the critics and scholars see it another kind of cultural dogma in Indian tradition and culture. Karman in Brahmanism is the moral duties of a man, which has to be

\footnotetext{
5 The purest amongst the other three Varnas in Indian tradition and culture of ancient India

${ }^{6}$ Bronkhorst, Johannes, Buddhism in the Shadow of

Brahmanism, Boston, Brill, 2011.

7 T.R.V. Murti, The Central Philosophy of Buddhism, London: George Allen and Unwin Ltd., 1960.

8 Andrej Ule, The Concept of Self in Buddhism and Brahmanism: Some Remarks, Asian Studies IV (XX), 1 (2016), Berlin, Wien, pp. 81-95
} 
performed with good intentions to achieve merits in future lives. Good karma will result in good merits and bad karma will lead to the bad effects in life and afterwards. Thus, the law of karma is based on the function of the moral reprisal of the actions. The notion of the karma is oriented to get rid of from the cycle of rebirth and get a place in the heavenly world and absorbed into Brahman or having unity with God.

d.) The Gods- Brahmanism should not be confused with Vedism in terms of its concept of existence and philosophy, but it is well argued that the great Gods and deities are inherited from Vedism into Brahmanism. The gods are an integral part of Brahmanism and remained the core of the Brahmanic cult and cultural system of it. In comparison to the Vedism, Brahmanism is limited in manifold ways of their status, divinity, and philosophy. The gods are supreme in Brahmanism, who bestow long life to the devotees, richness, and decide the destiny of life after death. Such favours are always desired in Brahmanism by its followers, but liberation cannot be obtained by divine grace rather one has to practice or develop the highest aspirations and submit him/her to a strict intellectual and moral praxis. In Brahmanism, such kind of achievements of moksha is not, open for all instead it is reserved for few privileged people in the Brahmanical society. Synchronism between old Gods and new gods is seen in Brahmanism. Gods enjoyed a prominent place in Brahmanic cult.

e.) The Rites- Religious rites in any tradition are performed to increase or decrease the role of Gods. Rites are performed to please their Gods and get kindness for a better life. The Brahman as "priest," the experts in the rite is responsible to perform any rite in the Brahmanical system. Brahman, highest in the caste system in the Indian society used to reflect the importance of rites in human life and at the same, they fix certain norms for others to avoid any kind of conflict-related to the rites. Thus, Brahman is responsible for the performance of rites; regulate the norms of the rite, strengthening of Brahmanic belief and magical inspiration as well. Moreover, the rites in Brahmanism play a very important role and are seen in multiple forms at the time of rituals, marriage, birth, a succession of king $^{9}$ etc. The rites in Indian tradition and culture are transmitted from generation to generation with or without certain changes in course of religious development. Rites in Indian society are initiated even before the birth (rites of conception) of a child and continue even after the death (postmortem rites). ${ }^{10}$

\section{CONCLUSION}

Brahmanism as a whole in Indian tradition and culture is noteworthy in the metaphysical, philosophical, and religious levels. It created a social system based on caste, which was hierarchically organised. Theoretically, Brahmanism as a distinct cult in ancient India framed society and the role of people based on the religious lines. Everyone in the Brahmanism has to follow these religious elements to be the essential part of the Brahmanical system, a system that has been legalised by the Brahmanic codes. Brahmanism in the initial phase of development of religion was considered as a religion, which in the later stage became a priestly religion closely associated with the rulers of the society to which it belonged. It tries to develop a society based on a single culture, and a single language. Its association with the ruling class was to provide the ritual services to them on different occasions.

\section{REFERENCES}

[1] Gonda, Jan, Vedic Literature, Wiesbaden: Otto Harrassowitz, 1975, and M. Winternitz, A History of Indian Literature, Vol. I, Introduction, Veda, National Epics, Puranas and Tantras, New Delhi: Oriental Books Reprint Corporation, 1972.

[2] Kane, P.V., History of Dharmasastra, Vol. II, Part I and Part II, Poona: Bhandarkar Oriental Research Institute, 1941.

[3] Johannes, Bronkhorst, Buddhism in the Shadow of Brahmanism, Boston, Brill, 2011.

[4] Murti, R.V., The Central Philosophy of Buddhism, London: George Allen and Unwin Ltd., 1960.

${ }^{9}$ Raj Bali, Pandey, Hindu Saṃskāras. A Socio-Religious Study of the Hindu Sacraments, Banaras:

Vikrama Publications, 1949.

${ }^{10}$ P.V., Kane, History of Dharmasastra, Vol. II, Part I and Part II, Poona: Bhandarkar Oriental Research Institute, 1941.. 
[5] Pandey, Raj Bali, Hindu Saṃskāras. A Socio-Religious Study of the Hindu Sacraments, Banaras: Vikrama Publications, 1949.

[6] Tola, F., and Dragonetti, C., "An2ditva or Beginninglessness in Indian Philosophy", in Annals of the Bhandarkar Oriental Research Institute, Vol. LXI, 1980, pp. 12-14, and "El an2ditva (inexistencia de comienzo) en la Filosofía de la India”, in Revista Venezolana de Filosofía No. 13, 1980, pp. 140-143

[7] Ule, Andrej, The Concept of Self in Buddhism and Brahmanism: Some Remarks, Asian Studies IV (XX), 1 (2016), Berlin, Wien, pp. 81-95.

[8] William, M.M., Brahmanism and Hinduism or Religious Thought and Life in India: as Based on the Veda and other Sacred Books of the Hindus, New York, Macmillan and Co., 1891. 